\title{
Reflecting on Namibia's Position in the European Union (EU)-Southern Africa Development Community (SADC) Economic Partnership Agreements (EPAs) Negotiations and the Lessons for Africa
}

\author{
Charity Manyeruke \\ Department of Political and Administrative Studies, University of Zimbabwe \\ Email: nevanjic@gmail.com \\ Lawrence Mhandara (Corresponding author) \\ Department of Political and Administrative Studies, University of Zimbabwe \\ P.O Box MP 167, Mt Pleasant, Harare. Zimbabwe \\ Email:1mhandara@gmail.com
}

Received:November 19, 2012 Accepted:December 15, 2012 DOI:10.5296/jpag.v2i4.2731

\begin{abstract}
Negotiations for Economic Partnership Agreements (EPAs) between European Union (EU) and the African Caribbean and Pacific countries (ACP) have been on the spotlight since 2002. The negotiations seek to replace the Lome Conventions which provided for a one way non-reciprocal trading regime between the EU and the ACP countries. The paper examines the position of Namibia in relation to EPAs and the lessons that Africa can derive from Namibia's stance. Namibia which is negotiating under the Southern African Development Community (SADC) has declined to sign the Interim Partnership Agreements, besides initialing them in 2007, arguing that EPAs are not consistent with the objective of advancing African economies into competitive outfits in the global economy. Some of the sticking issues that need to be addressed concern EU's demand for trade liberalization and a near elimination of import duty on all EU products to ACP zone. The paper argues that the major lessons for Africa are that EPA negotiations are much a political activity in as much as they involve the advancement of collective national interest by the EU. The paper therefore implores African countries to safeguard both political and economic interest in the process in the same manner as their EU counterparts are doing. Again, the paper exhorts Africa to negotiate from a position of strength and refuse to give in to unfair trade terms given the evident competition that is looming between the West and the East to partner Africa in development matters.
\end{abstract}

Keywords: Namibia, EU-SADC, EPAs and Lessons for Africa 
1. Introduction

Since 1975 the EU-ACP trading scheme was guided by the Lome Conventions. The trading system was one way and non reciprocal providing ACP exports a guaranteed duty free access to EU markets. This trading arrangement was challenged by non-ACP countries facing trade barriers to the EU markets. The main concern was that EU-ACP trading relationships were not compatible with the principles of World Trade Organization (WTO). As such, EU-ACP trading arrangements were required to comply with WTO rules. It is this background that the negotiations for new Economic Partnership Agreements were initiated between EU and the ACP bloc. These negotiations started in 2002 and were suppose to be concluded by 31 December 2007. During the first phase the ACP countries were negotiating as a unified bloc. However, later on the ACP was divided into six regional blocs- Caribbean, Central Africa, East and Southern Africa and the Pacific region. Having failed to come up with a substantive conclusion by end of 2007, the EU proposed Interim Economic Partnership Agreements (IEPAs) which will give a guaranteed access of ACP products to EU markets. This paper is concerned about Namibia's position, which initialed the IEPAs with reservations and later declined to sign before its concerns are addressed. Namibia is negotiating under the SADC configuration. Namibia's position exposes insincerity on the party of the EU and the weaknesses within the EU itself that the ACP countries can utilize in their bargain for better concessions. More importantly Namibia's position will also help the ACP states to better understand adverse implications of the full EPA agreements.

\section{An Overview of SADC- EU EPA Negotiating Principles}

The Cotonou Agreement outlines guiding principles that should be followed by the SADC configuration during the negotiations. There are three fundamental aspects that make up core principles within the SADC configuration. The SADC-EU EPA negotiations should lead to development of African economies. This emanates from the poverty eradication objective and the present level of development in SADC region. Trade liberalization is one major tool to achieve this goal. However, “...given the structure frailties of SADC-EPA economies, it is clear that trade liberalization in itself will not lead automatically to economic growth and sustainable development" (www.ecdpm.org). More so, the development and poverty eradication objectives should not be used only to attract the EPA countries to sign the agreement. Measures should be put in place to ensure that the intended objectives will be achieved.

The second guiding principle is that the EPA should complement rather than substitute SADC regional integration process and indeed in the rest of the ACP block. Note should also be taken on the point that the EPAs were intended to be designed in a manner that would facilitate a full implementation of the SADC Trade Protocol. SADC regional integration programmes need to be further established in several areas for example, appropriate institutional and legal bodies are required.

The third principle concerns the aspect of differentiation and asymmetry among individual SADC countries. This principle requires that special differential treatment, not limited to longer transitional periods and technical assistance and which may go beyond WTO rules, is 
to be granted according to the differences in size, economic vulnerability and levels of development among the various SADC countries (www.ecdpm.org). Special attention is required for the least developed countries in the region. Moreover, the EPAs must incorporate WTO compatibility and move from a preferential to a reciprocal trade regime as well as improved access to the EU market. Again this principle reinforces or gives support to Namibia's position as EPAs are likely to reduce accessibility of SADC-EPA products to the European Union.

The EU has been exposed on its insincerity to the spirit of the Cotonou Agreement through the way it approached the negotiations. The introduction of the so called "new" issues by the EU to the EPA negotiating agenda is highly unacceptable for the developing countries. These controversial new issues include investment, competition and transparency in public procurement (www.stopepade/img/epas-hidden-dangers-dangerrada65do.pdf). These have been removed from the WTO agenda as a response to pressure from Third World countries and a number of Non-Governmental Organizations. The problem now is that the EU wants developing countries to accept what they were denied at the WTO through signing EPAs. What can be discovered by ACP countries is that at WTO the developing countries managed to resist the inclusion of the so called new issues because they were united. Now, the solidarity of the ACP countries has been undermined as they negotiate within six different blocs leaving the EU in a position to continue pressing aggressive demands. The EU is pushing for new issues far much beyond the demands at the WTO level. For instance, EU was calling for transparency of public procurement at the WTO level, currently in EPAs it is calling for liberalization of public procurement as the basis of non-discrimination. Liberalizing public procurement will mean that the ACP governments will not be able to give first priority to domestic industries. Such industries will face immense barriers to penetrate European markets. At the end, domestic industries would be shoved out of business by multinational corporations.

\section{Namibia's Concerns over EPAs}

In 2008, the SADC-EPA configuration stated that all contentious issues need to be resolved before they could sign the initialed agreement. On the other side, the EU insisted that the signing of the initialed IEPA was a pre-requisite for addressing contentious issues. The SADC-IEPA configuration governments argue that it was meaningless to sign an agreement which contained substantial provisions with which they remained in fundamental disagreement. Later divisions arose within the SADC-EPA configuration, and this gave rise to a group known as the ANSA group (Angola, Namibia and South Africa. This group has actively pushed for substantive resolution of issues of concern as means of moving forward with the IEPA process. The other countries that are negotiating under SADC signed the IEPA with the EU. This could have been as a result of the fear to lose access to EU markets after the expiry of WTO waiver in 2007.

Namibia's concern is that Africa requires flexibility, an uninterrupted policy space, for its development agenda (acp-eu-trade.org/newsletter/acp-eu-trade). As such Namibia called on the EU to take a step backwards from the current excessive demands in the EPA negotiations 
to allow Africa the policy space which it requires to advance its development agenda. This stance by Namibia will lead other SADC countries to revisit the EPA agreements to assess their impacts on development of their economies. Ja-mare Duddy further quoted Peter Katjavivi, who spoke on behalf of the Namibian National Assembly (NA) Speaker Theo-Ben Guriab in the Belgium capital, argued that the EU demands will not provide for greater equity as they will perpetuate Africa's underdevelopment. Peter Katjavivi added that as Africans they would like to see significantly more measured approaches in the negotiations between Europe and the developing world with respect to issues raised around the EPAs (acp-eu-trade.org/newsletter/acp-eu-trade). More importantly, developing countries should not be worse off after the conclusion of these negotiations. This has stimulated some fierce debate on whether the proposed trading arrangement will ultimately lead to the development of third world economies especially in Africa.

The Namibian government expressed worries over the likely revenue losses if the full EPAs came into force. The elimination of tariffs for EU imports in SADC countries would harm the government revenue positions in these countries (www.africa-eu.org/). After signing the EPA, African countries would be required to eliminate tariffs on $80 \%$ of imports from the EU (www.africa-eu.org/). The effect is that African countries will be deprived of vital income which on average constitutes about $25 \%$ of their revenue collections (www.africa-eu.org/). This will not be a problem if the gains from increased trade will compensate for such losses. The worst case scenario is that African governments will be forced to make downward adjustments on their fiscal expenditure. Experience reveals that the reduction in the flow of revenue collections will put social programmes at risk and lead to poor service delivery in key areas such as health and education.

However, when considering that SADC countries may raise indirect taxes such as value added tax (VAT), the increased imports from EU will lead to increase in revenue collections. If this is the case, the revenue shortfall anticipated should taper-off. This will only take place if the elasticity of the VAT and other indirect taxes is significantly higher than the import duties. It is unlikely that the additional indirect taxes revenue will outweigh the revenue forgone from the import tariff. There is also likelihood that raising indirect taxes would affect consumer welfare as prices of goods and services would go up. As indicated earlier, in most developing countries revenue collections through import tariff and duties contribute significantly to national budgets and national development projects. Any reduction in revenue adversely undermines the country's capacity to implement such programmes. Nevertheless, current studies indicate that revenue forgone in SADC countries is likely to have negative impacts on government programmes. This analysis will lead one to argue that while on paper the EPAs seek to bring into being a trading arrangement that will assist ACP countries to develop their economies; the realities on the ground indicate the opposite. Thus when participating in these negotiations there is need on the part of ACP to consistently refer back to the main objectives of the Contonou to establish whether the design of the final EPA will lead to the realization of such objectives or not.

Namibia, Angola and South Africa have reservations over the provisions dealing with the prohibition of quantitative restrictions that would have an immediate impact on the use of 
import licensing arrangements to manage trade in sensitive food and agricultural products and as a tool for the promotion of the structural development of certain national sub-sectors. Agriculture is the backbone of almost all SADC countries; hence a trading arrangement that will negatively affect its viability will be a blow to the total economic performance of the whole region. If agricultural products are going to be liberalized for ACP countries this might lead to problems in relation to food security. African industries need government protection until such a level when they can compete with other industries from outside.

More so, the removal of tariffs on EU- products entering ACP markets will have negative effects on the agricultural sector. Once tariffs are cut there will be an inflow of cheap subsidized cereals from EU into the region that will bring down the prices of agricultural commodities thereby shoving local producers out of business and consequently depriving them of their source of livelihood. Local producers will be set to compete with industries and suppliers from the world's most economically advanced region whose products are highly subsidized. These fears can be made real by what has happened in other countries that have opened up their agricultural markets for EU producers. In Jamaica, for instance, the removal of tariffs for agricultural products has led to the influx of dairy products from the EU since early 1990s. Since then, EU has more than tripled its exports to Jamaica and has established itself as the major source of imported powder milk claiming about $67 \%$ of the Jamaican market (www.stopepa.de/img/epas-hidden-dangers-dangerrada65do.pdf). It was again discovered that the total number of milk producers in Jamaica was reduced from around thousand in the 1960s to less than a hundred in the 1990s. Similar scenario would happen to any of the countries that have signed and those that are intending to sign EPAs with the EU.

Another major concern raised by Namibia as well as Angola and South Africa is that the provisions banning the use of export taxes would undermine the promotion of value added processing in certain agricultural product chains. The affected products will include both traditional and non-traditional products. The African Renewal of October 2008 quoted the Namibian Ambassador to Brussels, Hanno Rumpf, complaining that insistence by EU that SADC governments should stop using export taxes and levies to create incentives for local companies to add value to goods will hinder regional development efforts (www.un.org/ecosocdev/geninfo/afrec). This is mainly because such government interventions were meant to promote greater exports of manufactured products than to relying on exporting raw materials.

Namibia, Angola and South Africa are also arguing that some of the provisions of the IEPAs are not compatible with existing South African Customs Union (SACU) infant industry protection provisions, which would undermine the use of EPA as a policy tool to promote food security. These EPAs are impacting most notably on certain wheat based products (www.agritrade.cta.int). This is true considering that European farmers are heavily subsidized. This will result in an unfair competition with SADC farmers who hardly get government support and if they do the processing is so taxing.

Namibia had voiced that EPAs will undermine regional integration efforts in Southern Africa. SADC member states are negotiating EPAs within five separate configurations, each with 
different tariff dismantling obligations, different product coverage and different schedules for tariff reductions. South Africa's Deputy-Director General for Trade and Industry, Xavier Carim argues that such developments could certainly complicate and possibly foreclose efforts to foster deeper regional integration in SADC and might call for strengthening of customs controls and rules of origin controls within the region (www.agritrade.cta.int/Agriculture/Topics/EPAs). There is a strong conviction that any breakdown of effective customs cooperation or the reintroduction of border controls is likely to undermine emerging regional trade in food and agricultural products. In support of this argument, Gumisai Mutume notes that, while other countries within a similar regional trading bloc are opening their markets for EU products through the signing of IEPA, those that refused to sign will be forced to maintain robust border controls to prevent smuggling of European goods (www.agritrade.cta.int/Agriculture/Topics/EPAs). Obviously such controls will hamper intra-regional trade. In this regard, it is clear that having a country such as Namibia taking a radical position and refusing to sign the IEPA, other countries are set to benefit as this will unpack more issues that will bring negative effects to ACP countries. The aspect of regional integration is not an issue for Namibia alone but a concern for all SADC member states and other regional trading blocs within the ACP group.

Namibian government notes that another factor undermining regional integration lies in the EU proposal of 2008 to retrofit the EU-South Africa Trade Development and Cooperation Agreement (TDCA) and the SADC IEPA tariff elimination commitments in order to ensure the integrity of SACU common external tariff. The proposal included extending the phase-in period for tariff reductions under the TDCA on some 33 tariff lines and accelerating the implementation of tariff reductions under the TDCA on some 320 tariff lines, in exchange South Africa will receive improved access to certain agricultural items and industrial tariff lines. It was noted by Angola, Namibia and South Africa that this tariff proposal left unaddressed a range of trade-related issues. Thus the ANSA group responded by submitting a joint demarche to EU member states outlining their concerns over EU approach to addressing contentious issues and the implications of that approach to regional integration. The demarche stated that the proposed solutions by EU reflected lack of flexibility and will exacerbate differentiation between South Africa and other members of SADC and SACU. The demarche added that the proposed solutions will create additional trade policy divisions in the region.

Whilst EU approach to regional integration is likely to affect regional integration initiatives in ACP countries, it is important to consider how the ACP countries themselves have been derailing integration efforts. There are certain aspects and factors that cannot be attributed to EU. Gumisai Moremi, the Executive Secretary of SACU, writing in the Namibian Editorial, contends that instead of undermining regional integration efforts, EU is in fact contributing to regional initiatives through financial support to regional organizations (www.accessmylibrary.com/article). Gumisai further argues that EU cannot be blamed for the choices made by SADC states negotiating an EPA with EU. This is true since such decisions have been made by sovereign states. However, this is not the correct observation according to analysts such as Gumisai Mutume who argues that it is the EU that, instead of 
negotiating with the ACP countries through their regional groupings, had created special negotiating blocs (www.un.org/ecosocdev/geninfo/afrec/).

Furthermore, the EU has been blamed for having hidden agendas by choosing to negotiate with ACP countries through regional groupings. According to Van Criekinge Tine, when the EU-ACP Lome trading framework was challenged for its incompatibility with WTO, the EU had to give heavy concessions in order to obtain WTO waivers (www.ies.be/node/450). By so doing, EU had jeopardized its negotiating position vis-a vis emerging powerhouses of the developing world such as China, Brazil and India. Through giving such heavy concessions EU is said to have negatively affected its position to securing its global interests. As such, EU is using EPA as an instrument to secure its own interests to reinstate itself as a giant international trading bloc.

Van Criekinge Tine contends that, “...EU's instrumentalist motives are more pronounced by EU's preference to regionalizing the ACP under the new trading framework" (www.ies.be/node/450). Manfred Elsig notes that "...economic objectives alone such as, trade gains influence in upcoming markets and competitive advantage cannot sufficiently explain why the EU has chosen to promote a regional framework in relations with third parties" (www.aei.pitt.edu/7809/1/elsig-m-01d.pdf). Manfred Elsig also notes that a regionalist approach helps the EU to construct significant spheres of political influence as well as gaining economic influence (www.aei.pitt.edu/7809/1/elsig-m-01d.pdf). The EU had a broader mission of creating a multi-polar world. In other words EU wants to export and reinforces its regional integration model as a success story (www.aei.pitt.edu/7809/1/elsig-m-01d.pdf). Indeed, it is being viewed as an ideal model for regional integration. Africa needs to look beyond what the EU is promising and explore other hidden motives. In this regard, the ACP states should not be used to legitimize the European model of integration while they are undermining their own.

Namibian officials raised concern over the relative legal status of the IEPA text which it is being asked to sign. The IEPA has an annex text attached to it that contains compromise provisions agreed to in Swakopmund. The argument being raised by the Namibian government is that IEPA text is governed by a broad body of international trade law, while the latter and annexed text have virtually no legally enforceable status. Such a scenario could affect or undermine Namibian government's right to use its traditional agricultural trade policy tools. These trade policy tools have been instrumental in food and agricultural sector development.

The European Union has consistently insisted that it wants trade in services to be part of full EPA agreement. Namibia opposed this arguing that services are key sectors in the region that need government protection. This sector particularly covers travel and tourism, education, health related services, transport and financial services (www.ecdpm.org). Liberalization of trade in services under an EPA coupled with the negotiations at the WTO level in the context of the General Agreement on Trade in Services would increase international competition posing the region serious economic social and environmental challenges (www.ecdpm.org). African governments have argued that if their markets are to be opened for European service 
providers it would be unfair to expect companies from the developing countries in the region to compete on equal basis with European companies (www.ips.org/africa). Namibia's Deputy Finance Minister, Calle Schlettwein, notes that, “...it would, for instance, give German operators access, to Namibian market, but on the other hand it is very unlikely that Telcom Namibia Ltd will go to take over Deustche Telkom" (www.ips.org/africa). This is indeed a sound argument, but one which is short sighted and blind to the technological revolution which is currently taking place. Due to current technological revolution it is becoming increasingly difficult for governments to institute tight controls in relation to trade in services. As such the fundamental question that should be addressed is how African countries can strategically position themselves to protect their industries as well as being sensitive to global changes.

Commenting on the General Agreement on Trade Related Services (GTRS), Issa Shviji notes that liberalization of services will force African governments; "...to open all national doors so as to provide free entry to the giant corporations of the North" (Shivji 2009) This argument can also be raised to explain the dangers associated with liberalizing trade in services under EU-ACP negotiations. The fear is about unfair competition that will negatively affect African companies to the benefit of European ones.

Contrary to the above opinion, some analysts have argued that liberalization of services could also lead to gains in terms of greater access to the EU market and attraction of foreign direct investment. SADC negotiations should ensure that full use is made of the flexibility allowed in GATs provision in terms of special and differential treatment in line with the outcome of the Doha Round and necessary adjustment and support measures for foreign competitiveness and supply side capacity are efficiently delivered in the region.

Tralac Executive Director, Trude Hartzenberg, noted that "liberalization can enhance competitiveness of trade in services and for Africa this should present opportunity to improve domestic regulatory frameworks...in the absence of a services development agenda, consumers pay the price for expensive service delivery by domestic and inefficient state owned companies" (www.ips.org/africa). This kind of analysis is coming to the fore because African governments such as Namibia have raised concerns of liberalization of trade. The current debate is attracting analysts to explore how the liberalization of services through EPAs will affect development in ACP countries. Those who support the proposed liberalization of services gives African governments an opportunity to design policies that will make them benefit from such initiatives. The question will not be about whether services should be liberalized or not, but about how strategically the African governments and companies should position themselves to maximize benefits.

Trude Hartzenberg notes that, the risks of liberalization are overstated, and further argues that, "...South African firms in the services sector have established commercial presence in telecommunications, financial and other services in most Southern African countries already without any liberalization" (www.ips.org/africa). More importantly, she noted that such services are hard to keep out because they often involve foreign direct investment (www.ips.org/africa). Again, it is not only the EPA agreement that will regulate the 
operations of external companies in Southern Africa. The feared service providers would be subject to domestic regulations. A classic example in this regard is that a handful of SADC countries have and are still implementing indigenization economic empowerment policies. South Africa, Namibia and Zimbabwe are some of the countries that have institutionalized such policies.

There is need for African governments to consider how efficient service delivery can be linked to economic development. Trude Hartzenberg further notes that, “...even in least developed countries, services contribute an increasing share of economic activity in terms of employment. Services are also very important for the manufacturing sector" (www.ips.org/africa). It is not possible to be competitive in manufacturing if there are no competitive services inputs. In Zimbabwe, for instance poor service delivery by state owned operators has been cited as the major challenge in increasing productivity. Trude Hartzenberg notes with concern the higher bank and telecommunication charges in Southern Africa as compared to other parts of the world and which are sometimes of poor quality. This, she said will not only hamper business development but have adverse effects on consumers and households (www.ips.org/africa). What then is needed is not to increase protectionist policies but to strengthen regulatory frameworks within the African countries as well as to push for the alignment of EPAs with domestic policies such as economic empowerment.

\section{Possible Alternatives to the EPAs}

Failure to conclude an EPA should not be regarded to as a death nail to the continuation of EU-ACP trading relationship. This is because possible alternatives can be explored that will still be compatible with the WTO principles at the same time giving the ACP countries opportunity to develop their economies. Article 37.6 of the Contonou Agreement provides that, the EU will assess the situation of the Less Developed Countries (LDC), and if they are not in a position to enter into EPAs, possible alternatives will be explored and utilized. The aim of examining such possible alternatives would be to create a new framework that is in line with the needs of the developing countries.

Jon Mortensen notes that Article 37.6 of the Cotonou Agreement should be read together with Article 37.7 which states that, "negotiations of the economic partnership agreements shall aim notably at establishing the timetable for progressive removal of barriers to trade between the parties, in accordance with the relevant WTO rules" (www.nai.uu.se). Article 37.7 also requires the negotiations to be conducted in a manner that shall take account of the level of development and socio -economic impact of trade measures on ACP countries as well as their capacity to adapt to the vagaries of liberalization (www.nai.uu.se). The EU has been accused of failure to leave up to its obligations since no alternative options were given to the ACP countries. According to the DIIS, the two articles states that negotiations should lead to a progressive removal of barriers to trade between parties; improving current market access for the ACP counties to the EU market; review the rules of origin; flexibility in establishing the duration of a transitional period; flexibility in the final product coverage; flexibility in the degree of symmetry in tariff dismantlement and at the same time being WTO compatible (www.nai.uu.se). Throughout the negotiations, EU was not sincere to the spirit of the 
Cotonou Agreement. In fact no flexibility was indicated, while the concept of WTO compatibility was prioritized above everything else and was used to justify outrageous demands.

Although no alternative option was offered by the EU to the ACP countries, it is pointless to continue blaming the EU while the ACP countries are doing nothing. According to DIIS, the EU contends that no single ACP country has requested the EU to examine alternatives, and moreover there are no WTO compatible alternatives, except the GSP scheme (www.nai.uu.se). The paper indicated that within the developing world, there are emerging markets that can provide alternative markets for African products. There is need for African countries to strengthen their cooperation with the East so that the EU will not see itself as the sole market for African products.

\section{Divisions within the EU: An Opportunity for ACP}

Namibia's position on EPAs exposed great divisions within the EU, in relation to the best approach to conclude the EPAs. What is important in relation to the existence of such divisions within the EU is that the ACP countries will realize possible weak points within the EU and put all their efforts so that they will gain more concessions from the EU. Refusal to sign the interim agreements is a power testing gesture on the part of EU and how flexible it is going to be. This flexibility will obviously be of an advantage to the ACP countries.

Following the continued pressure from most ACP countries including Namibia that the contentious issues should be resolved first, some EU member states also expressed their displeasure with the EU approach to the EPA negotiations. Some EU member states such as the UK, Denmark, Ireland, and Netherlands expressed concern regarding the block's inflexibility in reaching agreement with the ACP on contentious issues (www.ies.be/node/450). In March 2005, the UK, through its Departments of Trade and Industry (DFTI) and Department of International Development (DFID), released a highly critical position paper in which the government communicated its position on the content and context of the EPA negotiations. Through this paper, the UK expressed its views arguing that the final EPA document should reflect ACP countries' development needs, concerns, current capacities and where a lack of agreement existed; the EU should provide the ACP with alternative agreements which continue to provide the same market access the ACP had always enjoyed with the EU (www.ies.be/node/450).

The EU proposal to incorporate trade in services and other trade related areas into the EPAs was also attacked by other EU member states. This is one of the areas where Namibia has expressed its reservations. In this regard in 2005, Poland vehemently opposed EU's insistence on integrating 'non-essential' elements into EPAs (www.ies.be/node/450). Allan Hudson writes that the Polish position paper noted that, “...the ACP countries should not be burdened with additional requirements related to the instrument, competition or government procurement" (www.ies.be/node/450). The fact that some countries within the EU expressed their willingness to consider the concerns of ACP countries is a welcome development that calls for ACP countries to seize such an opportunity. The ACP countries should not be worried of losing the preference in European market and rush into signing trade packages that 
carry within them detrimental effects to their economies. The major lesson here is that there is a possibility that the EU will eventually back down and give in to the demands of the ACP countries. The moment when the EU is exposing its internal divisions, the ACP countries should unite and exert pressure on the EU.

A high level EPA meeting convened by the Commonwealth Secretariat in early 2008 in Cape Town, South Africa, ended with a conclusion that even if some countries have signed IEPAs, they still retain the right to demand renegotiation to ensure the agreements' consistency with national and regional development plans and aspirations (www.un.org/ecosocdev/geninfo/afrec). This is likely to help if the EU is going to be sincere to the spirit of the EPAS considering that development cooperation is one of the essential guiding negotiating principles on EPAs. Recently, Namibia has been assured that it will not lose its access to European markets for its beef and other agricultural products regardless of its failure to sign the IEPAs. This gives a ray of hope for the SADC EPA configuration that the EU is likely to back down and it will eventually compromise in the final document.

\section{Lessons for Africa}

The position taken by Namibia brings to the fore a number of lessons for Africa, if at all it is to assume a central role in the global economy. The most important lesson to derive from the entire debate is that abrupt and forced trade liberalization on African economies is inimical to economic development at this stage. Liberalization is good but it should be implemented gradually. If there is anything that African economies desperately need at this point, it is the aspect of protectionism. It is an open secret that EU economies boomed when they employed maximum protection strategies and later on 'opened up' when their industries developed the muscle to compete internationally. The United Kingdom, for instance, adopted free trade only after its industry had developed behind the shield of protectionism. Africa therefore needs to protect its nascent industry from what has been characterized as 'imperialism of free trade'. This concept, as propounded by John Gallagher and Ronald Robinson, means that free trade is but another form of economic imperialism (www.mtholyoke.edu). Embracing the EU free trade agenda will be catastrophic for Africa because the developed industries of the sponsor of the concept will enjoy massive advantages over the poorly industrialized African economy. This will make it extremely difficult for African economy to develop its industry into a competitive entity in the global economy. Therefore, the responsibility is upon Africa to assent to EPAs whose text facilitates and propels the agenda of state building and the acquisition of industrial power, which according to development blue prints in many developing countries is a primary goal of domestic policy. The EPAs tabled by EU at the moment do not acknowledge this prerequisite hence the need for Africa to withhold its assent.

The above point is not to suggest that Africa should be overprotective of its infant industry all the time. This is because of the fact that, while there is ample evidence to the effect that every country has protected its industries to some extent in the early stages of its industrialization, it does not necessarily follow that protectionism leads to the development of a viable industrial structure. The important lesson is that protectionism by Africa should be of a reasonable extent that does not allow for the superior EU industries to wipe out or destroy its industrial 
base; but simultaneously devise strategic trade regimes that enable its economy to seize opportunities provided by the EU economy in order to realize its economic objectives.

It is most important for African negotiators to be consistently aware of the fact that the call for the elimination of tariffs on EU imports to Africa will destroy its industry and encourage the growth of the former's. African industries are mostly agro-based and this bestows an obligation upon the African negotiators to safeguard agriculture, and indeed the rest of the other economic sectors, by agreeing to tariff reductions without jeopardizing domestic economic goals. What Africa needs to understand is that the objective of tariff reduction is to ensure easy market access rather than the complete abandonment of national controls over trade barriers. Thus Africa should agree to EPAs that contain patent provisions that protect against harmful domestic impact as a result of elimination of tariffs on EU imports to the continent.

Further lesson for Africa is that trade is also used as an instrument of foreign policy. Various policies such as trade and development, enlargement and humanitarian aid have acquired growing foreign policy relevance and are often used as instruments in the pursuit of the EU's foreign policy objectives abroad (www.ies.be/node/450).

Van Criekinge notes that "...trade negotiations function as instruments for reaching economic objectives (through economic means), while simultaneously offering a tool which will promote political objectives" (www.ies.be/node/450). Sophie Meunier and Kalypso Nicolaidis distinguish between power in trade and power through trade, with the former referring to EU's sheer economic size and strength and the latter, referring to the EU's increasing use of access to huge market as a bargaining chip to obtain changes in the domestic policies of the trading partner (Sophie \& Kalypso, 2005). The positions being advanced in the EPAs reveal EU's keenness in shaping both global and economic policies and international trade. What this implies is that Africa should also view EPAs in the same manner as the EU does. Africa should refuse to continue to be used by the EU to subscribe to its economic model that disregards Africa's ability to develop its own competitive model of economic development.

Another important lesson for Africa is that with signs of failure of the capitalist model of economic development becoming increasingly evident, there is justification in approaching the EPAs with caution and suspicion. It is the EU that is desperately in need of economic partners in Africa more than anywhere else because of the latter's growing strategic importance in the global economy. Africa need to understand that EU's position and reputation on the continent has been dented and compromised by the emergence of a vibrant South-South consciousness and the phenomenal rise of the Chinese economy and its strategic presence on the continent on favorable trade terms which are less rigid than proposals until the terms of the trade are 'fair' to the developing economies. Africa should not be affected by the political and economic superiority of the EU in the negotiations because the EU is likely to concede to Africa's demands as a way of keeping the Chinese at away. It is in the interest of the EU not Africa to have the EPAs signed sooner rather than later. This point is also buttressed by the divisions that hit the block over the issue that some African countries have 
expressed reservations over. The approach being taken by EU leads to a compelling but logical view that EPAs are an opposing force to deeper regional integration in Africa.

\section{Conclusions and Areas for Further Research}

The paper analyzed the Namibian position in relation to EPA negotiations which seek to bring into existence a new trading framework between the EU and the ACP countries. It has been highlighted that, the manner in which the EU is approaching the negotiations is not consistent with the objectives of the Cotonou Agreement. The EU is negotiating with ACP countries as a unified organization while at the same time the ACP countries are being divided into separate regional groupings. In this regard EPAs are not increasing deeper regional integration for the ACP countries. These are several lessons for Africa that can be drawn from Namibia's position in relation to EPAS. Most importantly, Africa needs to learn to protect its infant industry from EU's developed industry. There is also need for Africa to learn that EPAs are being used by EU to reassert its global economic influence. Namibia is a positive example to African countries that research is always important before finalizing any negotiations. Adequate stakeholder consultations and contextual analysis as being adopted by Namibia results in better bargaining processes. Rushed signatures in international and regional conventions should now be regarded as archaic and out of sync with the enlightened Africa. In this way the implications of this study are related to national policy impact of decisions of regional bodies. National policy makers should always be alert of the fact that the new agreements proposed will bring little change to the current trade situation in Africa. It is therefore critical for thorough research to be initiated on the implications of the partnership agreements before commitment is made. The area which needs more research in this regard is whether there is any value for African countries to continue with a barren trade relationship with the EU in view of the lucrative partnerships that can be fostered within the South grouping, especially with the emergence of Brazil, Russia, India, China and South Africa as potent economic centres.

\section{References}

Alan H, "Case Study on EU External Trade Policy: Economic Partnership Agreements," in Van Criekenge Tine, "Implications of Economic Partnership Agreements (EPA) On the EU-ACP Partnership and Possibilty of ACP Leverage," London School of Economics, accessed 13, 2010. http://www.ies.be/node/450.

Gallagher, J and Robinson, R "The Imperialism of Free Trade," The Economic History Review, Second Series, Vol. VI, no.1, 1953, accessed October 19, 2010. http://www.mtholyoke.edu/acad/intrel/ipe/gallagher.htm.

Gumisai M, "New Trade Pacts Threaten Regional Unity", Africa Renewal, accessed October 13, 2010. http://www.un.org/ecosocdev/geninfo/afrec/.

Hanno H, "The African Renewal", accessed October 12, 2010. http://www.un.org/ecosocdev/geninfo/afrec/.

http:// www.agritrade.cta.int/en/content/viewfull/2994. 
In Brief 14F: "Overview of the Regional EPA negotiations: SADC-EU Partnership Agreement," accessed October

12 , 2010. http://www.ecdpm.org/Web_ECDPM/Web/Content/Navigation.nsf/index2?readform.

Ja-mare Duddy, "Namibia asks EU to step back", The Namibian, 17 September 2010, accessed October 12, 2010. http://acp-eu-trade.org/newsletter/acp-eu-trad

Jon M, "The Trade-aid relation in EPA Negotiations: Core Controversies," Danish Institute for International Studies, accessed October 2010. http://www.nai.uu.se/events/archives/conferences/commodities/mortensen.pdf

Moremi,C "SACU Spells out its Nuanced Position on EPAs," The Namibian, October 29, 2008. http:// www.accessmylibrary.com/article. Accessed October 12, 2010.

Manfred E, "Delegation and Agency in EU Trade Policy-Making: Bringing Brussels Back in," World Trade Institute, accessed October 13, 2010. http://aei.pitt.edu/7809/1/elsig-m-01d.pdf.

Romain Perez and Stephen N Karingi, "How to Balance the Outcomes of the Economic Partnerships Agreements for Sub-Saharan African Economies?" United Nations Economic $\begin{array}{lllll}\text { Commission for } & \text { Africa, accessed }\end{array}$ http://www.africa-eu.org/content/download/2619/.../EPA\%20paper.pdf.

Servaas van den B, "Africa: Services Should Only be Liberalized if Properly Regulated," IPS Africa, accessed September 19, 2010. http://www.ips.org/africa/2010/09/.

Shivji, I. Where is Uhuru? Reflections on the Struggle for Democracy in Africa, Cape Town, Pambazuka Press. 2009.

Sophie M, and Kalypso N, " The European Union as a Trade Power," in International Relations and The European Union, Oxford University Press, Christopher Hill, 2005, 257.

Tara N, S, "EPAs are Bad for Africa," accessed October 15, 2010. http:// www.newera.com.na/article.php?

http://www.stopepa.de/img/epas-hidden-dangers-dangerrada65do.pdf, accessed October 13, 2010.

Xavier C, "An Analysis of SADC-EU EPA Process", accessed on October 12, 2010. http:// www.agritrade.cta.int/Agriculture/Topics/EPAs 